\title{
THE COMMUNITY TRUST
}

BY HUGH JACKSON REBER

Chicago

7 HE community trust movement is significant because it indicates the awakening of thinking citizens to a realization of a great civic need existing to-day, the need for a machinery whereby endowment funds may be safeguarded and applied forever to the changing requirements of the public good. The two great aims of the community trust are these: first, to offer a certain and permanent means whereby the income of endowment funds may be directed to meet the most urgent needs of each generation, and, second, to increase the popularity of this form of charitable bequest so that the endowments may become an ever-growing factor for community improvement.

Especially significant is the belief that under existing conditions there is available for endowments only a small percentage of the money that might be expected if more attractive conditions were provided for prospective donors. The records of the past endowments are filled with examples showing that planning for a perpetual benefit is one of the most difficult tasks conceivable. Each generation has its own needs of varying importance, and each has its own method of meeting them. The methods and aims of one generation are almost certain to be more or less inapplicable to the requirements of succeeding generations, and more significant yet is the fact that each generation must distribute its own burden and plan for itself in order to secure co-ordination in community enterprises. There is no better example of the lack of and need for united planning than our past endowments, in witness whereof may be cited Philadelphia's alleged over-supply of hospitals. So it happens that the establishing of an endowment is generally attended with great difficulties, if not uncertainties, and that this form of giving is not in favor.

\section{THE CLEVELAND TRUST}

The origin of the new idea was in 1913 when Frederick H. Goff, president of the Cleveland trust company, proposed a plan whereby his trust company might agree to accept gifts to constitute a community foundation or trust, the income of which might be expended for the advancement of the social interests of the community in a manner to be determined each year by a representative committee. The proposal was at once received with hearty commendation by great numbers of publicspirited citizens, and on January 2, 1914, a formal resolution was passed by the company's board of directors, putting the plan in actual operation. 
The first two years of the fund's existence have resulted in gifts and pledges amounting to more than $\$ 30,000,000$. Now in infancy this new institution promises to return more than a million dollars each year for community betterment. What this vast source of income will mean to a city of 600,000 inhabitants can scarcely be conceived. Even now the responsibilities of the committee in charge of disbursing the income are felt to be so great that a comprehensive survey of local conditions and needs is being undertaken. If confidence in the fund continues, it must eventually grow to many times its present size.

During the year 1914 no other community trusts were established, but in 1915 the success of the original plan became generally known and in six large cities of the country trust companies undertook to follow Cleveland's example. These cities are St. Louis, Spokane, Chicago, Milwaukee, Los Angeles, and Boston. In January, 1916, a somewhat altered form of foundation was established in Indianapolis. Community trusts are being considered in a number of other cities to-day.

As might be expected, the form of organization of the "Cleveland foundation" served as a model for most of the others; especially in St. Louis, Spokane, Chicago and Milwaukee. The Los Angeles and Indianapolis trusts include radically new features.

In the Cleveland plan the power to expend the income of the fund is vested in a committee of five, a member being appointed each year, to serve without compensation for five years. One member is appointed by the city's chief executive, one by the senior judge of the federal district court, one by the senior judge of the probate court, and two by the board of directors of the trust company. The committee's expenses are paid out of the fund, though its permanent secretary is selected by the trust company. The committee has no power over the management of the trust; it is responsible merely for disposing of the yearly net income reported to it by the trust company trustee.

It is provided that the principal may be expended to a limited extent only when the committee and the directors of the trust company agree. A two-thirds vote of the directors is necessary. Donations to the fund may or may not indicate a particular use to be made of the gift in question, but in any event the wishes of the donor may be set aside. In this matter also the directors must approve the action of the committee. A majority vote of the directors is required. The powers of the trust company as trustee of the foundation are very great. Unless limited by the terms of the donation, it may invest and reinvest as it sees fit and in any form of security, loan or real estate. In return for its services, it receives such compensation as it may for itself determine to be due. It is empowered also to list for taxation the amount of the foundation in spite of laws exempting such funds. 
In case any essential part of the plan for expending the moneys of the foundation is set aside by action of the courts, the directors of the trust company are vested with the authority given the committee, or if the defect can be remedied, the directors shall reconstruct the organization so that it may as nearly as possible carry out the original intention. Provision is made for an annual audit and public statement of income and expenditures.

Almost all of the details and even the methods of expression of the Cleveland agreement are found in succeeding plans. Los Angeles was the first to introduce any strikingly original features. In this city the body having charge of the expenditures is a committee of five with a self-perpetuating membership. Two members must be members of the board of directors of the trust company. All five are originally selected by the trust company. The trust company retains the power also to alter at any time the form of organization in any manner that circumstances may seem to it to warrant so long as such changes do not interfere with the charitable purposes in view. As regards the powers of the company in its capacity of trustee, and in other less important features, the Los Angeles plan is similar to the others.

\section{BOSTON'S PERMANENT CHARITY FUND}

The next community trust to be established was in Boston; it is known as the "permanent charity fund." Here a committee of seven is provided instead of those of five members. It is essentially the Cleveland plan. The attorney-general of the state appoints one of the extra members and the trust company the other. The five year term is continued. No method of listing the fund for taxation is mentioned nor is there provision made for expending any part of the principal of the fund. The committee without the assent of the trust company may set aside special directions of donors as to how sums are to be spent, but such action requires affirmative vote of five members.

\section{INDIANAPOLIS PLAN}

The Indianapolis plan adopted January 5,1916 , is briefly set forth in a resolution passed by three trust companies. Each one agrees to accept donations for "the Indianapolis foundation." The donor may limit absolutely the uses for which his gift is to be used. The committee to which is given the power of making disbursements is composed of six members, two appointed by the chief executive of the city, two by the senior judge of the federal district court, and two by the senior judge of the court having jurisdiction over the settlement of estates. There is no provision for spending the principal other than that possible in the terms of gift. The funds cannot be listed for taxation if exempted by law. The powers of the trust companies are not enumerated and, there- 
fore, are the usual legal powers granted to similar foundations, subject to the terms of the various gifts.

In coming to any conclusion as to the merits of the several community trusts which have been established thus far and as to the probable ultimate results, it must be borne in mind that only those forms of organization which forever retain the confidence and interest of the people can entirely succeed. Upon the confidence and interest of the public depends their support and, therefore, their ability to do good. The enormous resources which may be expected to accumulate if the funds succeed in establishing themselves as the final solution of the problem of endowments can be guessed from the success which has so far attended the "Cleveland foundation."

In this age of tremendous and ever increasing demands for civic work, the problem of financing the thousand and one community undertakings is a problem of far greater significance than it has ever been before. It calls for the best genius and most determined effort that can be summoned for the public welfare. Waste and indifference can no longer be tolerated. Every available source of revenue must be wisely drawn upon, and expenditures must be so planned that the existing needs may be cared for in proportion to the urgency of each. Not only have community activities increased in number and volume, but they have become more and more necessary to society. This is especially true in cities.

If the problem of endowments can be successfully solved, it will tend to relieve each generation of the strain placed upon it, and it will make possible additional public service. The endowment represents social saving, the production and setting aside of capital for the benefit of all. Its accumulation, spread perhaps over a great period of years, is a burden to no one.

\section{OBJECTIONS TO CLEVELAND PLAN}

It is a regrettable fact that in planning the community trust in Cleveland more care was taken to safeguard the interests of the trust company than those of the people. This was due not so much to the lack of perception of the founder and his colleagues, as to the newness of the idea and the natural caution with which the matter was approached.

The fundamental objection to the Cleveland plan is that it fails to provide for complete community control and, therefore, fails to establish the trust fully as a community foundation. Most noticeable is the appointment of two of the five members of the committee by the company. This arrangement is specially objectionable because there is only one trust company concerned, instead of being a joint proposition of all trust companies. In a number of other particulars the directors of the company under the Cleveland plan indicate an unwillingness to leave the control of expenditures to community appointees, and in the handling 
of the principal of the fund, the interest of the public is in no way represented.

It is upon its claim for recognition as a community institution that the "Cleveland foundation" relies for special support and public interest of a sort that must be its best insurance of success. But under the present plan there are decided limitations upon the public nature of the trust and there is no guarantee that other foundations equally or more public in control might not arise to compete with the original fund for public attention. As a private or semi-public fund there is much that is admirable in the Cleveland organization, but as a public trust in its present form it is most uncertain to succeed so long as it is not firmly established as the single community institution with unified public control.

In Indianapolis the control over the fund so far as spending the income is concerned is wholly in the hands of men indirectly representative of the people, and the claim to community recognition can hardly be denied. But the basis of representation in Indianapolis and that employed for three members of the committee under the Cleveland plan is by no means perfect. In the Indianapolis scheme the method of appointing the committee seems to offer the greatest opportunity for criticism.

The theory that judges are particularly well fitted to select members of such a committee is based upon a too limited consideration of existing conditions. It is unwise in the first place to give important duties of a non-judicial nature to a judge. There are obvious reasons for this timehonored notion: first, a judge's fitness should be decided purely upon his record on the bench; second, the dignity of the court should not be jeopardized by unnecessary connections with affairs in which factional disputes may arise; and there are doubtless other good reasons. On the other hand, the cautiously selected nominees of the judges are not necessarily well qualified for active leadership. Experience has sufficiently established this fact at least with regard to appointments where professional excellence is not the criterion.

The mayor is much better qualified as an appointing officer. Through him is obtained consideration for the various elements in the community which might desire representation, and thus to a limited extent the advantages of diversity in point of view are obtained in the composition of the committee.

\section{COMMUNITY CONTROL}

It is certainly to be desired that the community trust may make its appeal for support to all classes alike. Failure to do so means a loss both in ability to accumulate funds and in ability to employ most effectively the yearly income. That the value of widespread community encouragement and co-operation was well recognized by the founders of the trusts 
is indicated to a greater or less degree by the forms of organization adopted and by the declarations made regarding the functions of the new institutions. It is doubtful, however, whether the form of control in any city does adequately carry out the intentions of the founders in this regard.

To carry out these intentions, the advantages of a diverse representation for the controlling body must be secured, or, if the present attempt to have purely general representation is continued, wider and more comprehensive points of view of the appointing officers are desirable. This is true primarily because purely general representation is impossible.

Other questions of organization might be raised upon the more or less satisfactory solution of all of which the success of the community trusts depends. For example, it seems doubtful whether the general representation aimed at should not be given up in favor of frankly special representation of the fields of social work. This and the present principle might possibly be combined to advantage. Again, serious doubt may be felt as to the adequacy of a board of control of five where the responsibility is so great and the field so wide. These and other similar matters deserve most careful consideration.

Of the questions which have been raised, the most vital are those concerning conditions which directly affect the status of the funds, either by tending to establish them on no higher plane than other similar quasipublic funds in the city or by tending to elevate each to the unique position of being its community's one public endowment institution. The community trust should occupy a more definite place in the machinery employed in civic work and should have a stronger and more certain support and co-operation from the other forces in the community than could any private organization. It should, in fact, mean a great stride toward united planning and co-operative action in social welfare enterprises, and so by virtue of its widely recognized worth may be expected to develop the latent possibilities of endowments viewed as a form of donation.

Present defects notwithstanding, the outlook for the community trusts is bright. Their existence promises their continuation and perfection in a form that will make possible their fullest community usefulness. This is true because only by satisfying the demands of each generation can any such fund keep the confidence of those who are in a position to contribute and to aid or to hinder its growth. Defective organizations will be set aside or, more probably, changed, and it is reasonable to assume that the best features will be retained and developed. 